\title{
Further considerations about "Detection and identification of enteroviruses circulating in children with acute gastroenteritis in Pará State, Northern Brazil (2010-2011)"
}

\author{
Raiana Scerni Machado ${ }^{1,2}$, Ivanildo Pedro de Sousa Jr. ${ }^{2}$, Jacqueline Cortinhas Monteiro 1,3 , James Lima Ferreira', \\ Jainara Cristina dos Santos Alves ${ }^{1}$ and Fernando Neto Tavares ${ }^{1 *}$ (B)
}

\begin{abstract}
On the detection and identification of enteroviruses circulating in children with acute gastroenteritis in Brazil: reply to Luchs, A. Comments on Detection and identification of enteroviruses circulating in children with acute gastroenteritis in Pará State, Northern Brazil (2010-2011).
\end{abstract}

Keywords: Enterovirus, Acute gastroenteritis, Brazil

\section{Dear Editor,}

We appreciate the opportunity to respond to the comments of Dr. Adriana Luchs, Adolf Lutz Institute, Brazil, on our recent paper published in the Virology Journal [1].

It is well-known that infections by enterovirus (EV) species are very common in the human population and are associated with a wide spectrum of clinically distinct syndromes affecting multiple body systems. Moreover, a high percentage of EV infections are asymptomatic. Although not recognised as medically important viruses causing acute gastroenteritis (AGE), the diarrhoeic potential of certain EV-types has been postulated in a number of surveillance studies [2-5]. Nonetheless, the role of EVs in the aetiology of AGE (including the newly recognised Picornaviruses Cosavirus and Parechovirus) still remains unclear since the vast majority of these earlier studies focussed solely on diarrhoea-causing

*Correspondence: fernandotavares@iec.gov.br

${ }^{1}$ Laboratório de Referência Regional em Enteroviroses, Seção de Virologia, Instituto Evandro Chagas, Ananindeua, Pará, Brazil

Full list of author information is available at the end of the article enteropathogens without inclusion of matched healthy controls. Therefore, we fully agree with Dr. Luchs' comments on our paper in that "Detection of EV strains exclusively must be interpreted cautiously".

It is worth mentioning that rather than assessing a possible causative relationship between EVs and AGE cases among hospitalised children, our study sought mainly to improve our knowledge on the genetic diversity of EVs circulating in our region. In this regard, as a Regional Reference Centre for Enteroviruses of the Brazilian Ministry of Health, we believe that our investigation was conducted in compliance with the scope of the Global Enterovirus Surveillance Program, as part of the WHO and National Public Health responses in support to the Polio Eradication Initiatives.

It is mentioned in Commentary VIRJ-D-21-00011 that "...none or the references cited [6] by Machado et al. stated the association of EV with acute diarrhea etc." In this regard, it should be noted that such references (some of which suggested by our paper' reviewers) related in fact to studies that reported the occurrence of EVs in the context of AGE-and other clinical syndromes-rather than establishing EVs as true diarrhoeagenic pathogens.

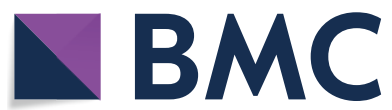

(c) The Author(s) 2021. Open Access This article is licensed under a Creative Commons Attribution 4.0 International License, which permits use, sharing, adaptation, distribution and reproduction in any medium or format, as long as you give appropriate credit to the original author(s) and the source, provide a link to the Creative Commons licence, and indicate if changes were made. The images or other third party material in this article are included in the article's Creative Commons licence, unless indicated otherwise in a credit line to the material. If material is not included in the article's Creative Commons licence and your intended use is not permitted by statutory regulation or exceeds the permitted use, you will need to obtain permission directly from the copyright holder. To view a copy of this licence, visit http://creativecommons.org/licenses/by/4.0/. The Creative Commons Public Domain Dedication waiver (http://creativeco mmons.org/publicdomain/zero/1.0/) applies to the data made available in this article, unless otherwise stated in a credit line to the data. 
We thank Dr. Luchs for her considerations regarding a comparison of neutralising antibody titres in acute and convalescent phase (paired) serum specimens, so that serological diagnosis of EV could also be achieved. This would certainly be suitable in light of classical virological procedures. Currently, however, EV serological-based tests seem more relevant to epidemiological investigations than to clinical diagnosis, since the use of molecular biology methods in clinical virology has significantly changed approaches towards laboratory diagnostics of EV infections. Furthermore, we have essentially followed recommendations provided by WHO in the Enterovirus Surveillance Guidelines for Enterovirus Surveillance in Support of the Polio Eradication Initiative [7], where stools remain the clinical sample of choice for EV diagnosis.

As can be noted in our short report published recently in the Virology Journal, we have essentially searched for EVs in stool samples which had previously tested negative for other potential viral enteropathogens including rotavirus, parechovirus etc. Yet, even in cases where these samples were found to be EV-positive we precluded from highlighting any aetiological relationship between these pathogens and AGE. Notably, however, we were able to demonstrate a relatively high enterovirus detection rate among AGE patients which appears not being commonly observed. In addition, our study results were consistent with previous reports where a very high proportion of co-circulating non-poliovirus enteroviruses (NPEVs) were demonstrated, particularly those strains belonging to the human EV species $C$ [6]. Of note, this might potentially give rise to recombination events which are known to often precede the emergence of novel evolutionary lineages of EVs. Further, we agree in that carefully designed studies are warranted to more accurately elucidate the role of EVs in the aetiology of AGE. These might typically be matched case-control studies where clinical and epidemiological data could be gathered, as well as data on the occurrence of other potential viral, bacterial and parasitic gastrointestinal pathogens.

\section{Conclusion}

Overall, the establishment of a correlation between NPEV and AGE is complex. Further studies must be conducted to refine methods of detecting both ongoing and recent infections in patients with AGE to establish a causal link with NPEV. Finally, we believe that the information provided in our short report essentially highlights the need for continuous monitoring of EVs in cases of AGE, which represents a potentially valuable strategy towards strengthening surveillance for non-polio EV system in Brazil.
Abbreviations

AGE: Acute gastroenteritis; EV: Enterovirus; WHO: World health organization.

Acknowledgements

Not applicable

Authors' contributions

All authors revised the manuscript.

Funding

Not applicable.

Availability of data and material

Not applicable.

\section{Declarations}

Ethics approval and consent to participate

Not applicable.

Consent to publication

Not applicable.

\section{Competing interests}

The authors declare that there are no conflicts of interest.

\section{Author details}

${ }^{1}$ Laboratório de Referência Regional em Enteroviroses, Seção de Virologia, Instituto Evandro Chagas, Ananindeua, Pará, Brazil. ${ }^{2}$ Laboratório de Enterovírus, Instituto Oswaldo Cruz, Fundação Oswaldo Cruz, Rio de Janeiro, Brazil. ${ }^{3}$ Laboratório de Virologia, Instituto de Ciência Biológicas, Universidade Federal Do Pará, Belém, Pará, Brazil.

Received: 23 April 2021 Accepted: 10 June 2021

Published online: 15 July 2021

\section{References}

1. Machado RS, de Sousa IP, Monteiro JC, et al. Detection and identification of enteroviruses circulating in children with acute gastroenteritis in Pará State, Northern Brazil (2010-2011). Virol J. 2020;17(1):156.

2. Pallansch MA, Oberste S, Whitton L. Enteroviruses: polioviruses, coxsackieviruses, echoviruses, and newer enteroviruses. In: Fields' Virology (eds. Knipe DM \& Howley P). vol.1. Lippincott Williams \& Williams; 2013. p. 490-53.

3. Rao DC, Babu MA, Raghavendra A, Dhananjaya D, Kumar S, Maiya PP. Nonpolio enteroviruses and their association with acute diarrhea in children in India. Infect Genet Evol. 2013;17:153-61.

4. Nagabushana D, Rao DC, Pushpalatha S. A clinical and epidemiological study of enterovirus associated diarrhea in a clinical and epidemiological study of enterovirus. J Pediatric Sci. 2014;6:e212.

5. Chansaenroj J, Tuanthap S, ThanusuwannasakT, Duang-in A, et al. Human enteroviruses associated with and without diarrhea in Thailand between 2010 and 2016. PLOS ONE. 2017;12(7):1-13.

6. Bessaud M, Pillet S, Ibrahim W, et al. Molecular characterization of human enteroviruses in the Central African Republic: uncovering wide diversity and identification of a new human enterovirus A71 genogroup. J Clin Microbiol. 2012;50(5):1650-8.

7. WHO. Enterovirus Surveillance Guidelines - guidelines for enterovirus surveillance in support of the polio eradication. Regional Office for Europe: World Health Organization; 2015. p. 2015.

\section{Publisher's Note}

Springer Nature remains neutral with regard to jurisdictional claims in published maps and institutional affiliations. 